\title{
Pelatihan Bahasa Inggris menggunakan E-learning bagi Anak Pekerja Pabrik Batu-Bata di Gampong Kajhu
}

\author{
Riyan Maulana ${ }^{1}$, Adi Ahmad 2*, Mujiburrahman ${ }^{3}$, Rizaldi Akbar ${ }^{4}$ \\ 1,2,3 Program Studi Sistem Informasi, Fakultas Ilmu Komputer, STMIK Indonesia Banda Aceh, Jl. \\ T. Nyak Arief No. 400, Kota Banda Aceh, Provinsi Aceh, Indonesia. \\ ${ }^{4}$ Program Studi Manajemen Informatika, Fakultas Ilmu Komputer, AMIK Indonesia, Jl. T. Nyak \\ Arief No. 400, Kota Banda Aceh, Provinsi Aceh, Indonesia \\ Corresponding Email: adiahmad@stmikiba.ac.id ${ }^{2}$.
}

\section{Article History:}

Received: Jul 29th 2021

Revised: Aug 15th 2021

Accepted: Aug 17th 2021

Keywords: Training;

English; E-Learning.
Abstract: This service involves village community leaders and village communities including children, youth, and community leaders. This method is carried out to understand the Kajhu community about: a) the weaknesses they experience and have, b) the community's desire to overcome their shortcomings, c) develop strategies and methods to solve problems, and d) help the community overcome, solve, and think critically to get a solution to the problem when learning English. Based on the implementation of KKN, it is known that 1) the people of Kajhu Village provide maximum support through enthusiastic participation and facilitation of community service activities, 2) community service training materials that are in accordance with community needs encourage enthusiasm for English language training, and 3) optimism for the realization of an English Club. in Kajhu Village is very high, which is shown by the seriousness of each party in participating in the process of activities carried out. 


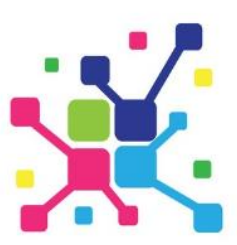

\section{Pendahuluan}

Seiring dengan penyebaran dan perkembangan dunia digital seperti internet, dan komputer yang cepat [1], kemunculan sebuah model pembelajaran yang dapat diakses dimanapun dan kapanpun sudah mulai terasa salah satuya menggunakan e-learning yang semakin diminati dan diadopsi oleh institusi pendidikan tinggi [2,3], apalagi dimanfaatkan untuk pembelajaran pada anak-anak [4,5]. Pembelajaran online model $e$ learning adalah salah satu cara yang sangat bermanfaat untuk mencapai berbagai kualifikasi seseorang [6,7]. Kemajuan teknologi sekarang memungkinkan siswa untuk belajar sepenuhnya secara online sambil tetap bersosialisasi dengan teman, menonton ceramah dan berpartisipasi dalam diskusi khusus subjek $[8,9]$.

Saat ini kita berada pada masa pandemic virus corona, di era revolusi industri 4.0, dimana dibutuhkan terobosan-terobosan teknologi yang tepat untuk mendukung proses pembelajaran di masa pandemic [10], apalagi bagi pembelajaran untuk anak- anak [11]. Pendidikan 4.0 merupakan pendidikan yang bercirikan pemanfaatan teknologi digital dalam proses pembelajaran atau dikenal dengan sistem siber (cyber system). Model pembelajaran era 4.0 ini mampu membuat proses pembelajaran dapat berlangsung secara kontinu tanpa batas ruang dan batas waktu [12].

Indonesia tergolong lambat dalam merespon revolusi industri 4.0, dibandingkan negara tetangga seperti Malaysia dan Singapura [13]. Sistem pendidikan 4.0 baru bergaung kencang dalam beberapa tahun terkahir [14]. Oleh karena itu, pemerintah harus menyediakan fasilitas yang memadai dalam menyongsong era Pendidikan 4.0 [15]. Dengan kondisi masyarakat desa yang menjadi sasaran dalam program PENGMAS 2020 di desa Kajhu ini, yang mayoritas berpenghasilan rendah dimana hampir 70 persen penduduknya bekerja sebagai buruh, petani dan nelayan menjadikan desa Kajhu salah satu desa yang yang tertinggal diantara desa lain dalam wilayah Kabupaten Aceh Besar. Permasalahan yang dihadapi oleh masyarakat adalah, rendahnya semangat dan motivasi dalam belajar khususnya bahasa inggris di desa. Masyarakat desa lebih cenderung bekerja mencari uang dan memebantu ekonomi keluarga dari pada harus pergi belajar yang faktanya tidak dapat menghasilkan uang. Fakta inilah yang mendorong pengabdian ini dilaksanakan untuk meningkatkan kualitas pembelajaran dan tingkat pendidikan pada desa Kajhu melalui pemanfaatan E-learning guna menunjang kecakapan dan skill masyarakat desa melalui program pelatihan bahasa inggris menggunakan e-learning untuk anak pekerja pabrik batu- bata di gampong Kajhu.

\section{Metode}

a. Metode Pelaksanaan Kegiatan

Metode pelaksaan yang telah dilakukan dalam kegiatan ini adalah motode ceramah dan selanjutnya praktek berbicara berkaitan dengan materi yang telah disampaikan 


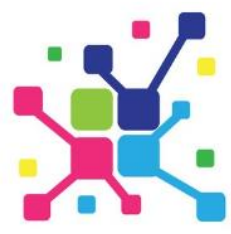

A J A D

Jurnal Pengabdian kepada Masyarakat

Vol. 1, No. 2, October, 2021, pp. 61-68

DOI : https://doi.org/10.35870/ajad.v1i2.14

melalui offline (tatap muka) dan online (E- learning/ WAG) yang telah didesain sedemikian rupa. Untuk lebih jelasnya dapat di lihat pada tabel 1 berikut:

Tabel 1. Metode Pelaksanaan

\begin{tabular}{|c|c|c|c|}
\hline Fase & Aktivitas & Keterangan & Target Output \\
\hline 1 & $\begin{array}{l}\text { Identifikasi } \\
\text { Masalah }\end{array}$ & $\begin{array}{l}\text { Menemukan masalah dari } \\
\text { kondisi desa sasaran yang } \\
\text { sudah ada, pada konteks ini } \\
\text { permasalahan } \\
\text { adalah; } \\
\text { a) Masih banyaknya } \\
\text { masyarakat yang tidak tau } \\
\text { dan tidak mau belajar } \\
\text { bahasa asing. } \\
\text { b) Mengemas pembelajaran } \\
\text { bahasa asing (bahasa } \\
\text { Inggris) yang bersifat } \\
\text { Practical dan menarikguna } \\
\text { menciptakan suasana } \\
\text { belajar yang asik dan } \\
\text { menyenangkan. }\end{array}$ & $\begin{array}{l}\text { List permasalahan media } \\
\text { pembelajaran yang ada saat } \\
\text { ini. } \\
\text { List kebutuhan yang akan } \\
\text { dikembangan. }\end{array}$ \\
\hline 2 & $\begin{array}{l}\text { Pencarian } \\
\text { Alternatif } \\
\text { Solusi }\end{array}$ & $\begin{array}{l}\text { Mencari alternatif solusi untuk } \\
\text { permasalahan yang sudah ada. } \\
\text { Metode yang digunakan untuk } \\
\text { mencari alternatif solusi } \\
\text { adalah penelitian kualitatif } \\
\text { dengan melakukan studi } \\
\text { literatur tentang kebutuhan } \\
\text { dan modifikasi modote } \\
\text { pembelajaran online berbasis e } \\
\text { learning. Hasil dari studi } \\
\text { literatur kemudian akan } \\
\text { dikelompokkan menjadi tiga } \\
\text { bagian yaitu hasil analisis } \\
\text { kebutuhan masyarakat, saran } \\
\text { desain model pembelajaran, } \\
\text { dan teknologi relevan yang } \\
\text { akan digunakan. }\end{array}$ & $\begin{array}{l}\text { Daftar teknologi dan teknik } \\
\text { yang akan digunakan untuk } \\
\text { memecahkan masalah. } \\
\text { Daftar aplikasi } \\
\text { pembelajaran online } \\
\text { berbasis e - learning yang } \\
\text { sudah beredar di pasaran } \\
\text { sebagai perbandingan }\end{array}$ \\
\hline 3 & $\begin{array}{l}\text { Implementasi } \\
\text { dan } \\
\text { Pengembangan } \\
\text { metode } \\
\text { pembelajaran } \\
\text { berbasis } \quad e- \\
\text { learning. }\end{array}$ & $\begin{array}{l}\text { Merancang sistem dengan } \\
\text { permodelan menggunakan E- } \\
\text { learning dan mengimplemen- } \\
\text { tasikannya dalam dunia } \\
\text { pendidikan untuk hasil } \\
\text { program yang lebih fleksibel } \\
\text { dan mudah diadaptasi pada }\end{array}$ & $\begin{array}{l}\text { Desaign awal dan tahapan } \\
\text { pembelajaran } \\
\text { menggunakan e- learning } \\
\text { untuk diuji cobakan. }\end{array}$ \\
\hline
\end{tabular}




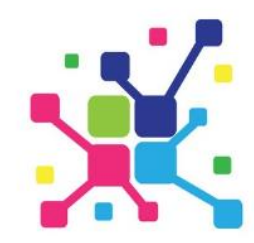

A J A D

Jurnal Pengabdian kepada Masyarakat

Vol. 1, No. 2, October, 2021, pp. 61-68

DOI : https://doi.org/10.35870/ajad.v1i2.14

\begin{tabular}{|c|c|c|c|}
\hline & & $\begin{array}{l}\text { beragam kebutuhan } \\
\text { pemebelajaran mandiri di } \\
\text { masyarakat. Pada tahap ini } \\
\text { integrasi sistem sudah } \\
\text { terwujud namun belum diuji } \\
\text { coba pada lingkungan nyata. }\end{array}$ & \\
\hline 4 & $\begin{array}{l}\text { Studi Kasus dan } \\
\text { Uji Coba } \\
\text { metode } \\
\text { pembelajaran. }\end{array}$ & $\begin{array}{l}\text { Menguji coba metode dengan } \\
\text { menggunakan beberapa media } \\
\text { pembelajaran baik pada } \\
\text { menggunakan aplikasi e- } \\
\text { learning maupun dari segi } \\
\text { model pedekatan CTL } \\
\text { langsung dalam masyakat } \\
\text { untuk memastikan media } \\
\text { pembelajaran berjalan dengan } \\
\text { baik. Kemudian media } \\
\text { pembelajaran juga } \\
\text { didiskusikan pada beberapa } \\
\text { pakar pendidikan seperti guru } \\
\text { dan dosen untuk mendapatkan } \\
\text { feedback dan masukkan. }\end{array}$ & $\begin{array}{l}\text { Umpan balik dari } \\
\text { pakar/ ahli untuk } \\
\text { meningkatkan kualitas } \\
\text { metode pembelajaran. }\end{array}$ \\
\hline 5 & $\begin{array}{l}\text { Evaluasi dan } \\
\text { Pembenahan }\end{array}$ & $\begin{array}{l}\text { Pada fase diskusi akan } \\
\text { didapati beberapa inputan } \\
\text { dari pihak ahli atau pakar. } \\
\text { Inputan tersebut akan } \\
\text { dievaluasi pada tahap ini } \\
\text { untuk kemudian ditentukan } \\
\text { bagian mana yang perlu } \\
\text { ditingkatkan atau bahkan } \\
\text { mungkin perlu dikurangi. }\end{array}$ & $\begin{array}{ll}\text { Daftar kekurangan } & \text { dan } \\
\text { penambahan metode. } & \end{array}$ \\
\hline
\end{tabular}

b. Waktu Efektif Pelaksanaan Kegiatan

Mengingat program ini dilaksakan pada masa pandemic selama 3 hari yaitu pada tanggal 25, 26 dan 27 Agustus 2020 dengan lokasi di Desa Kajhu Aceh Besar.

c. Tempat Kegiatan

Lokasi pengabdian ini dilaksanakan pada Desa Kajhu, Kabupaten Aceh Besar, Provinsi Aceh, Indonesia. Dimana lokasi Desa Kajhu juga sangat dekat dengan lokasi Perguruan Tinggi Tim Pengabdian, berjarak 3 KM dan dapat ditempuh 15-20 menit ke lokasi 


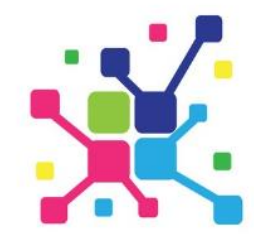

A J A D

Jurnal Pengabdian kepada Masyarakat

Vol. 1, No. 2, October, 2021, pp. 61-68 DOI : https://doi.org/10.35870/ajad.v1i2.14

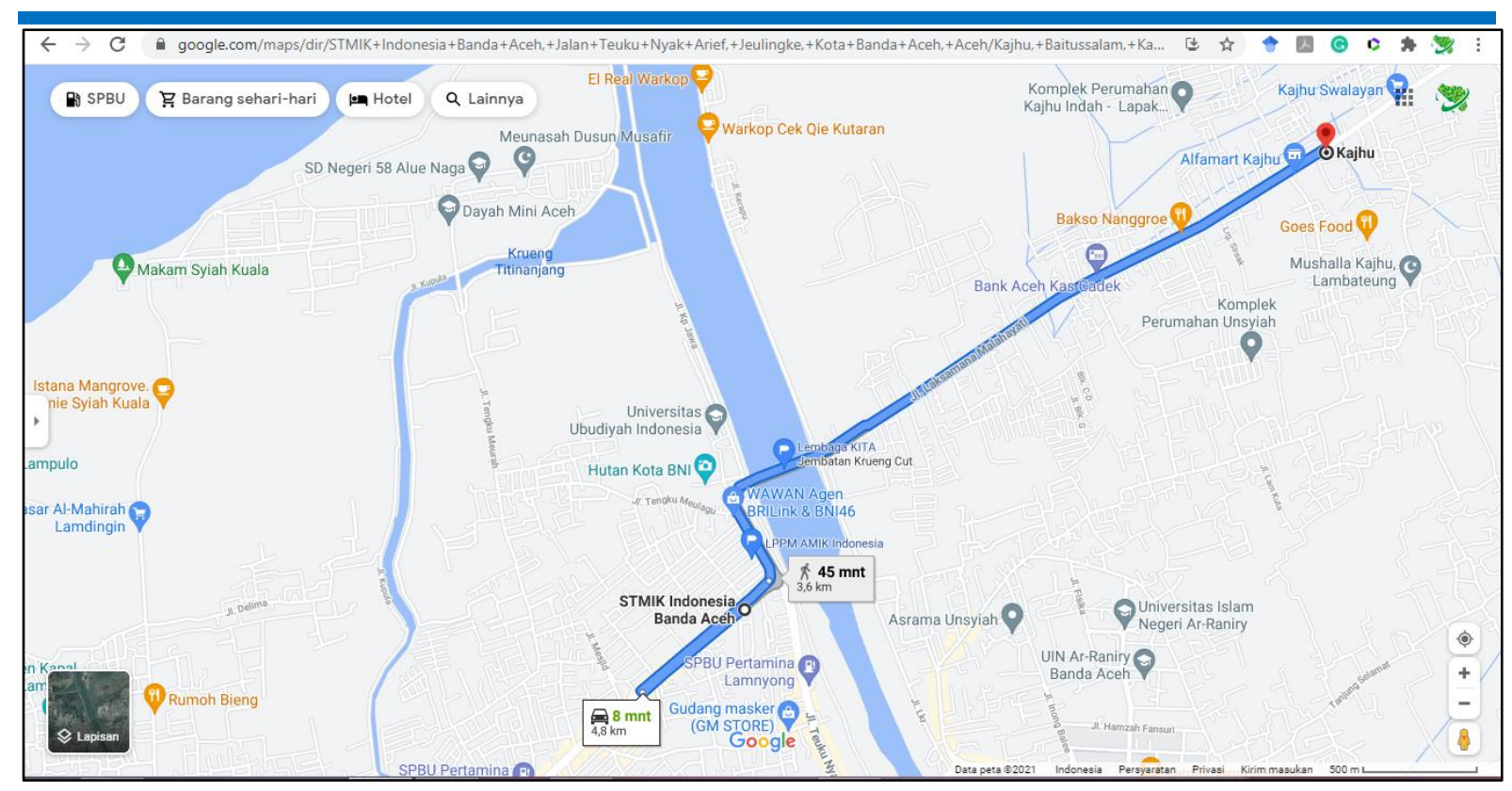

Gambar 1. Map Lokasi Kegiatan.

\section{Hasil}

Kegiatan pelatihan berkaitan dengan pelatihan bahasa Inggris untuk anak pabrik batu bata di Desa kajhu secara umum berjalan dengan lancar. Kepala Desa, kepala dusun dan tokoh- tokoh masyarakat membantu mempersiapkan tempat dan mengkoordinir peserta pelatihan. Peserta pelatihan merupakan mayoritas putra dan putri pekerja pabrik baru bata dengan rentang usia usia 9 sampai dengan 15 tahun. Tempat yang dipakai untuk kegiatan tersebut adalah Balee Laif Ba yang teletak di Blok I Desa lamseunong lama. Sebelum melakukan kegiatan pelatihan, pemateri memperkenalkan diri terlebih dahulu kemudian mencoba menggali pengetahuan dasar bahasa Inggris mereka. Pemateri mengajukan beberapa pertanyaan mengenai speaking dan praktek berbicara bahasa inggris. Setelah menggali pengetahuan dasar kemudian pemateri mulai memaparkan materi pendidikan bahasa inggris (speaking). Selama kegiatan pelatihan berlangsung tampak peserta antusias dan memperhatikan isi materi pelatihan. 


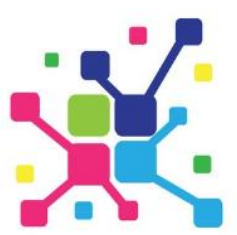

A J A D

Jurnal Pengabdian kepada Masyarakat

Vol. 1, No. 2, October, 2021, pp. 61-68 DOI : https://doi.org/10.35870/ajad.v1i2.14

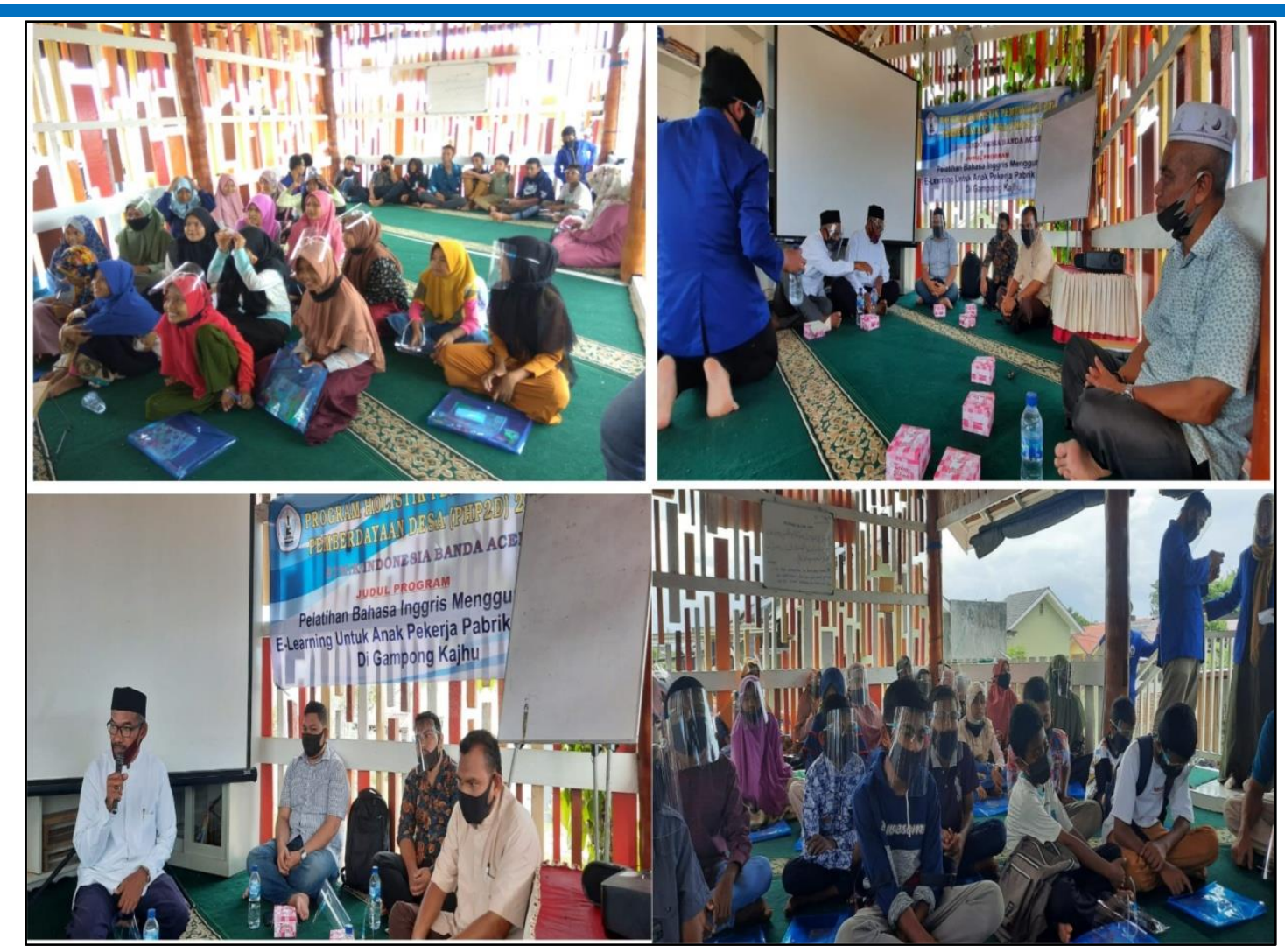

Gambar 2. Dokumentasi Kegiatan

Kegiatan pemberian materi berlangsung selama seminggu kurang lebih dan di akhir sesi pemateri memberikan kesempatan kepada peserta untuk mengajukan pertanyaan terkait materi yang telah disampaikan. Didapatkan 3 pertanyaan dari peserta pelatihan terkait isi materi. Setelah menjawab pertanyaan dari peserta, pemateri melakukan evaluasi terkait pemberian materi yang telah disampaikan dengan cara memberikan pertanyaan dan memberikan kesempatan kepada peserta untuk menjawab pertanyaan tersebut. Peserta yang mampu menjawab pertanyaan mendapatkan door prize sebagai tanda apresiasi dan setelah itu kegiatan pelatihan ditutup secara offline dengan kegiatan foto bersama antara pemateri dengan peserta pelatihan, dan selanjutnya dilakukan pembelajaran secara online melalui Whatssapp (WAG). Pembelajaran online ini dilaksanakan dengan cara diskusi lebih mendalam terkait dengan materi yang pernah dipelajari. Pembelajaran secara online ini juga dilakukan dalam klub bahasa inggris yang dilaksanakan setiap hari minggu jam 4 Sore di salah satu Warkop Banda Aceh bernama Aneuk Kupi yang dipimpin langsung oleh pemateri pelatihan yang telah ditunjuk.

\section{Diskusi}

Kegiatan pelatihan tentang pelatihan bahasa inggris menggunakan e-learning untuk anak pekerja pabrik batu- bata di gampong kajhu terlaksana dengan baik bahkan para peserta terlihat antusias dan mengharapkan kegiatan pelatihan ini dapat berlanjut 
dengan pemberian materi yang lainnya terutama terkait kebahasaan lainnya seperti bahasa Arab dll. Tokoh masyarakat juga mengharapkan akan adanya kegiatan yang berkelanjutan sehingga semakin dapat meningkatkan pengetahuan masyarakat desa terutama generasi muda.

\section{Kesimpulan}

Pelatihan ini merupakan pelatihan bahasa inggris menggunakan e-learning untuk anak pekerja pabrik batu- bata di gampong kajhu dengan proporsi teori $25 \%$ dan praktek $75 \%$, dengan proporsi demikian diharapkan peserta akan mampu menguasai dan menggunakan bahasa Inggris dengan benar. Pada akhir kegiatan Pelatihan ini akan diadakan uji kompetensi yang diikuti oleh semua peserta pelatihan. Secara khusus hasil yang diharapkan pada pelatihan bahasa inggris menggunakan e-learning untuk anak pekerja pabrik batu- bata di gampong kajhu bagi kalangan mahasiswa ini diharapkan dapat meningkatkan pemahaman peserta dan kemampuan teknis peserta dalam Bahasa Inggris. Program pengabdian kepada masyarakat ini sangat bermanfaat dan membantu terselakasanaya sebuah kegiatan pendidikan di lingkungan masyarakat. Diharapkan program pelatihan bahasa inggris ini dapat berlanjut guna mendorong dan mensupport mahasiswa kita untuk berkarya dengan mewujudkan ide- ide mereka.

Berdasarkan evaluasi dan monitoring yang dilakukan maka rekomendasi yang kami ajukan bagi kegiatan ini adalah:

1) Kegiatan serupa seharusnya dilaksanakan secara kontinyu untuk meningkatkan pengetahuan dan skill peserta mengenai bahasa inggris. Kegiatan dapat berupa pelatihan secara berkelanjutan kepada seluruh peserta secara intensif.

2) Diadakannya di grup- grup / English Club bahasa Inggris di tengah masyarakat.

\section{Daftar Referensi}

[1] Ibrahim, A. and Afrina, M., 2011. Pengembangan Model Perpustakaan Berbasis Teknolig Informasi Untuk Meningkatkan Kinerja Layanan Perpustakaan dan mewujudkan Perpustakaan Ideal Berbasis digital. Prosiding Konferensi Nasional Teknologi Informasi dan Aplikasinya (KNTIA2011), pp.C87-C94.

[2] Mastuti, R., Maulana, S., Iqbal, M., Faried, A.I., Arpan, A., Hasibuan, A.F.H., Wirapraja, A., Saputra, D.H., Sugianto, S., Jamaludin, J. and Arifah, F.N., 2020. Teaching from home: Dari belajar merdeka menuju merdeka belajar. Yayasan Kita Menulis.

[3] Wali, M., Ahmad, L., Akbar, R., Salam, A. and Ismail, I., 2020. Source Code Library (SCL): Software Development Learning Application. International Journal of Scientific \& Technology Research, 9(2), pp.175-182. 


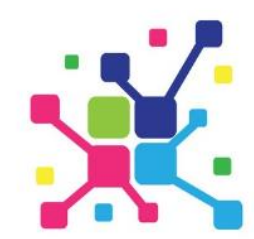

A J A D

Jurnal Pengabdian kepada Masyarakat

Vol. 1, No. 2, October, 2021, pp. 61-68 DOI : https://doi.org/10.35870/ajad.v1i2.14

[4] Irawan, E., Arif, S., Hakim, A.R., Fatmahanik, U., Fadly, W., Hadi, S., Pertiwi, F.N., Fauziah, H.N., Santoso, L., Pahlevi, F.S. and Hidayati, N., 2020. Pendidikan Tinggi Di Masa Pandemi: Transformasi, Adaptasi, dan Metamorfosis Menyongsong New Normal. Zahir Publishing.

[5] Maulana, R. and Ma'ruf, D., 2020. Model Media Pembelajaran Menggunakan Aplikasi Blanded Learning Berbasis Mobile.Jurnal Informatic, Education and Management (JIEM), 2(2), pp.54-61.

[6] Ahmad, L., Sufyan, S. and Ahmad, A., 2020. Pelatihan Penggunaan Software Content Admission Sebagai Implementasi dari Konsep Complement Online Learning pada AMIK Indonesia. Jurnal Pengabdian Nasional (JPN) Indonesia, 1(2), pp.41-46.

[7] Maulana, R. and Bahruni, B., 2020. An Android-Based Vocabulary Model For Autism. IJISTECH (International Journal of Information System \& Technology), 3(2), pp.221-226.

[8] Ahmad, A. and Al Bahri, F.P., 2020. Problem Based Learning Android App Innovation. IJISTECH (International Journal of Information System \& Technology), 3(2), pp.217-220.

[9] Biyansyahna, E. and Maulana, R., 2020. Meningkatkan Kosa Kata Bahasa Inggris Siswa Dengan Menggunakan Gambar.Jurnal Informatic, Education and Management (JIEM), 2(1), pp.55-72.

[10] DINA, I.S., 2020. Proses Pembelajaran Pada Masa Covid-19 (Tantangan dan Solusi). Minda Mahasiswa Indonesia: Kenali Industri 4.0 Hadapi COVID-19, p.61.

[11] Atsani, K.L.G.M.Z., 2020. Transformasi media pembelajaran pada masa Pandemi COVID-19. Al-Hikmah: Jurnal Studi Islam, 1(1), pp.82-93.

[12] Arti, M., 2020, May. Tantangan Sekolah Dan Peran Guru Dalam Mewujudkan Pembelajaran Bahasa Yang Efektif Di Era 4.0 Menuju Masyarakat 5.0. In Prosiding Seminar Nasional Program Pascasarjana Universitas Pgri Palembang.

[13] Saleh, M. and Ihsan, N., 2020, January. Pelatihan dasar perancangan teknologi tepat guna berbasis mikrokontroler Arduino pada siswa SMAN 1 Parepare. In Seminar Nasional Pengabdian Kepada Masyarakat (Vol. 2019, No. 9).

[14] Savitri, A., 2019. Revolusi Industri 4.0: Mengubah Tantangan Menjadi Peluang di Era Disrupsi 4.0. Penerbit Genesis.

[15] Wirawan, V., 2020. Penerapan E-Government dalam Menyongsong Era Revolusi Industri 4.0 Kontemporer di Indonesia.Jurnal Penegakan Hukum Dan Keadilan, 1(1), pp.1-16. 